\title{
Effect of Media Material on Biogas Production
}

\author{
0. T. Oginni1 ${ }^{*}$, O. L. Rominiyi², B. A. Adaramola², S. A. Babalola² \\ ${ }^{1}$ Department of Mechanical Engineering, Ekiti State University, Ado-Ekiti, Nigeria \\ ${ }^{2}$ Department of Mechanical and Mechatronics Engineering, Afe Babalola University (ABUAD), Ado-Ekiti, Nigeria \\ Email: *oginniolathomas@gmail.com, rominiyiol@abuad.edu.ng
}

How to cite this paper: Oginni, O.T., Rominiyi, O.L., Adaramola, B.A. and Babalola, S.A. (2017) Effect of Media Material on Biogas Production. World Journal of Engineering and Technology, 5, 540-549. https://doi.org/10.4236/wjet.2017.53046

Received: June 10, 2017

Accepted: August 20, 2017

Published: August 23, 2017

Copyright $\odot 2017$ by authors and Scientific Research Publishing Inc. This work is licensed under the Creative Commons Attribution International License (CC BY 4.0).

http://creativecommons.org/licenses/by/4.0/

(c) (i) Open Access

\begin{abstract}
The paper investigates the effects of the quantity of media materials with simple appraisal on biogas yields between hard and soft wood subjected to the same atmospheric condition in the Ado-Ekiti, Nigeria, between October 2009 and June 2010. Sixteen digesters were used and the mechanical grinding of cassava peels was done in a clean mortar and pestle. Specific grammes of cow dung and cassava peels $(200 \mathrm{~g}, 150 \mathrm{~g}, 100 \mathrm{~g}$ and $50 \mathrm{~g}$ ) were seeded with four substrates (woods) mixed up with $1200 \mathrm{~cm}^{3}$ of distilled water respectively. The appropriate ratios of the prepared slurries were transferred into different digesters for bio-degradation process which is third-fourth full with the aid of a funnel, and the tubes were passed into a measuring cylinder as a gas collector inverted over acidified water in a plastic vessels. The volume of biogas produced ranged from $6964 \mathrm{~cm}^{3}$ to $13,185 \mathrm{~cm}^{3}$ by Mahogany, and Iroko ranged from $5340 \mathrm{~cm}^{3}$ to $10,250 \mathrm{~cm}^{3}$ were obtained for both hard woods used. Likewise, the volumes of gas produced by soft woods were from $2465 \mathrm{~cm}^{3}$ to $6445 \mathrm{~cm}^{3}$ by Obeche and $3430 \mathrm{~cm}^{3}$ to $6990 \mathrm{~cm}^{3}$ by Araba. The results showed that, the highest percentage of the seedling media materials (33\% each) on the substrates (cassava peel and cow dung) produced the highest biogas with $2800 \mathrm{~cm}^{3}$ of Mahogany, $2400 \mathrm{~cm}^{3}$ of Iroko, $1200 \mathrm{~cm}^{3}$ of Araba and $1130 \mathrm{~cm}^{3}$ of Obeche woods respectively. It was established that, the rate of biogas yields is directly proportional to the quantity of the seedling materials to obtain a reliable results as an alternative renewable energy.
\end{abstract}

\section{Keywords}

Biogas, Media Materials, Anaerobic, Hard and Soft Woods, Slurry

\section{Introduction}

Society is today confronted with dwindling and depletion sources of fossil fuels and chemical feedstock, and battling with the proliferation of wastes generated by municipalities, agriculture and industries. The conversion techniques of re- 
newable resources or wastes to chemicals and fuels by microbial fermentation through a biogas reactor signifies a tremendous challenge for engineers in global technological stance, and the future ahead with respect to energy demand. Anaerobic biodegrading of cellulosic materials is a biological engineering process [1] in which a methane-rich gas (biogas) is produced and slurry that is of proven value as fertilizer and animal feed is left as a residue. Several works have been undertaken in improving biogas yield such as the pre-treatment of waste feedstock [2] which includes preheating, milling, chemical treatment with sodium hydroxide and other components. One of the major and relevant components of the process is the micro-organisms that are responsible for the enzymatic or catalytic breakdown of the feedstock and the subsequent conversion of methane, carbon dioxide and traces of hydrogen, nitrogen and hydrogen sulphide. The use of media materials to ensure a higher concentration of these micro-organisms would accelerate the rate of biogas yield by ensuring the passage of the three phases of gas production throughout the digester concurrently [3]. This affects the startup characteristics of the process positively [4]. The quantity and quality of media materials such as synthetic materials, wood species, and limestone are to be expressed in percentage of total volume appropriateness [4]. Generally, the organic matter must be highly degradable to achieve a large yielding gas. Conversely, lower gas production rates would result from less biodegradable wastes [5]. This work introduces the use of cassava peels seeded with local Nigeria wood species: 1) two hard woods namely Khaya species (meliaceae family) - Mahogany, and Milicia excelsa (moraceae family)-Iroko; 2) two soft woods namely Triplochiton scleroxyon-Obeche and Cieba pentandra (bombacaceae family) —Araba, as media materials that are unique.

\subsection{Types of Biogas Plant}

The classification of digesters is based on the method of slurry feeding.

\subsubsection{Integrated Continuous Plants}

These are used for small plants with capacities of up to about $14.16 \mathrm{~m}^{3}$ digester slurry volume. They have only one digester. The gas holder dome is directly over the digester slurry purposely to produce biogas for lighting, ironing clothes and cooking family meals, and bio fertilizer for the crop lands and fish ponds. The plant is provided with mixing a tan where the flesh slurry is prepared and charged into digester. The sludge empties into a decantation tank [6].

\subsubsection{Split Continuous-Fed Plant}

These have horizontal continuous fed digesters. Each digester has an inlet and outlet pipe. Several rows of digesters may be constructed with common sides, but each digester should have its own sump. A medium size split-continuous fed plant has one floating dome gasholder, but a large plant has two or more. The gasholder forms a separate unit; the carbon dioxide scrubber forms another unit. Biogas for used in internal combustion engines shall be passed through a hydrogen sulphide scrubber [6]. 


\subsubsection{Stage Continuous-Fed Plant}

This plant has three chambers and is used, if so desired, to produce some biogas from night soil. The night soil flows to the primary chamber while the wash water from the kitchen, bathroom and laundry flows to the third chamber. The biogas is recovered from both the primary and secondary chamber; the latter produces much less gas. The most convenient manures to use are those that are dry like that of poultry. The sludge moves from the primary chamber to the secondary chamber then to the third chamber.

\subsubsection{Batch-Fed Plant}

This plant have many digesters as the number of days of retention time plus one so that one digester is discharged and charged with slurry every day. In case of extreme necessity, there shall be at least one-half as many digesters as the number of days of retention time plus one, thus discharging and charging one digester every two days. Manure more than two days old is a poor producer of biogas. Keeping the manure too long before use would also cause pollution. The batch fed digester is used when crop residues are mixed with manure particularly when it is designed to recover paper pulp materials. This plant consists of two lines of single chamber digesters place side by side and back-to-back so that three sides of each digester are common in order to save on construction materials and reduced the walls exposed to the ambient temperature [5].

\subsection{Components of Biogas Plants}

Anaerobic digestion of organic waste takes place in a tank of many forms of construction referred to as a digester and also a gas collector (gas holder) together with purification units: 1) The digester; 2) Heating digesters; and, 3) Gasholders. There are two types of gasholders namely; the fixed dome type and the floating type.

\subsection{Substrates for Biogas Production}

A variety of substances are used for biogas production namely;

1) Farm Wastes: Examples are pig, cattle, sheep, poultry and other ruminants [7].

2) Municipal Wastes: Examples are meat packaging and slaughter house waste; fish processing waste, bleaching clay from edible oil production; dairy waste and brewery and distillery wastes [8].

3) Energy Crops: Examples are lucerne, sugar beet, grass leaves, seaweed, and water hyacinths [9].

\subsection{Biogas Composition}

The basic gas producing reaction in the digester is carbon plus water to give methane plus carbon dioxide. Thus;

$$
2 \mathrm{C}_{(g)}+2 \mathrm{H}_{2} \mathrm{O}_{(c)}-\mathrm{CH}_{4(c)}+\mathrm{CO}_{2(g)}
$$




\subsection{Factors Affecting Biogas Production}

Various factors such as biogas potential of feedstock, design of digester, inoculums [10], nature of substrates, $\mathrm{pH}$ ( $\mathrm{PH}$ range of 7.5 - 8.5), temperature [11], loading rate, hydraulic retention time (HRT) [12], C.N ratio, volatile acids [13] and other factors influence the biogas production.

\section{Materials and Methodology}

Mahogany, Iroko, Araba, Obeche sawdust, cassava peels, cow dung, acidified water.

\subsection{Collections and Preparation of Raw Materials}

Organic samples used for anaerobic digestion were collected from Ado Ekiti metropolis. Freshly voided cattle waste (cowdung) was collected from agricultural farm whereas, fresh cassava peels were obtained from a garri-processing unit Aba Egbira. Quantity of Khaya species (Mahogany), Milicia excelsa (Iroko), Triplochiton scheroxylon (Obeche) and Ceiba pentandra (Araba) were collected from Ayisola sawmill. These trees were chosen as a source of seedling material on the basis of its availability and concentration of cellulose material in the wood content.

\subsection{Setting up the Digesters}

Sixteen (16) digesters were used as anaerobic digesting process. In setting up a digester, an appropriate ratio of waste and distilled water transferred into a digester which is third-fourth full with the aid of funnel. Next was the mechanical grinding of cassava peels using a clean mortar and a pestle. Cow dung and cassava peels of $200 \mathrm{~g}$ each was seeded with $200 \mathrm{~g}$ of Mahogany wood and mixed with $1200 \mathrm{~cm}^{3}$ of distilled water $(1: 2 \mathrm{w} / \mathrm{v})$. The prepared slurry was transferred to the digester A. Also, $200 \mathrm{~g}$ of cow dung and cassava peels each was seeded with $150 \mathrm{~g}$ of Mahogany wood, mixed with $1200 \mathrm{~cm}^{3}$ of distilled water and the slurry was transferred into digester B. Likewise, was $200 \mathrm{~g}$ of cow dung and cassava peels each seeded with $100 \mathrm{~g}$ of Mahogany sawdust and mixed up with $1200 \mathrm{~cm}^{3}$ of distilled water and later transferred to digester C. Finally, $200 \mathrm{~g}$ of cow dung and cassava peels each was seeded with $50 \mathrm{~g}$ of Mahogany sawdust mixed with $1200 \mathrm{~cm}^{3}$ of distilled water and the resulting slurry was transferred into digester D. Similarly, the aforementioned experimental procedure analysis was step wisely followed as tabulated below in their media composition of digester slurries.

Table 1 below shows the right proportion of slurry loading ratios in their various digesters.

Similarly, the loading of other digesters were as followed via Mahogany: A - D, Iroko: I - L, Araba: E - H, Obeche: M - P, respectively for the purpose of the research.

$$
C P=\frac{Q}{W}
$$


Table 1. Media composition of digesters' slurries (Mahogany: A - D, Iroko: I - L, Araba: E - H, Obeche: M - P).

\begin{tabular}{cccccc}
\hline $\mathrm{D}$ & $\mathrm{C}(\mathrm{g})$ & $\mathrm{CP}(\%)$ & $W(\%)$ & $\mathrm{V}_{\mathrm{w}}\left(\mathrm{cm}^{3}\right)$ & $\mathrm{S}_{\mathrm{w}}(\mathrm{g})$ \\
\hline $\mathrm{A}$ & 200 & 33 & 33 & 1200 & 1800 \\
$\mathrm{~B}$ & 200 & 36 & 27 & 1200 & 1750 \\
$\mathrm{C}$ & 200 & 40 & 20 & 1200 & 1700 \\
$\mathrm{D}$ & 200 & 44 & 11 & 1200 & 1650 \\
\hline
\end{tabular}

Where, $\mathrm{D}$ is the digester; $\mathrm{C}$ is the cow dung; $\mathrm{CP}$ is the cassava peel; $W$ is the wood; $\mathrm{V}_{\mathrm{w}}$ is the volume of water and $S_{w}$ is the weight of slurry.

where, $Q$ is the quantity of cassava peels; $C P$ is cassava peel in percentage and $W$ is the sum of the wastes.

However, the digesters were airtight using rubber corks overlaid. With a tube filled through the holes, the tubes were passed into measuring cylinders inverted over acidified water in plastic bowl. The cylinders were used as a measuring scale as well as gas collectors. The acidified water was prepared by adding $0.05 \mathrm{ml}$ sulphuric acid to $18.4 \mathrm{w}$ of water in the ratio 1:368. Acidified water was used to prevent the biogas from dissolution into the water while the digester was corked to generate an anaerobic condition. The volumes of biogas produced were recorded at a specified interval of 4 days for duration of 40 days. In the course of the experiment, the ambient temperature was $35^{\circ} \mathrm{C}$ with a continuous loading rate. The cow dung in the digester has a retention time of 14.5 days and maintained a process stability of a recommended $\mathrm{pH}$ range $6-8$. A pH range meter was used to detect its acidity or toxic period. A solution of alkaline was used to control the $\mathrm{pH}$ value. The slurry in the digester was mixed and stirred periodically to:

1) Prevent the settling of the bacteria at the digester base and maintaining firm contact between bacteria and manure properly.

2) Prevent surface scum formation of the slurry in the digester.

3) Facilitate the release of biogas.

\subsection{Laboratory Preparation of Acidified Water}

Maramba described the experimental set up of anaerobic fermentation and explained that, an ordinary gallon bottle or reagent bottle can be used as a digester in a laboratory. He further described a representative equation for charging a digester [6].

$$
D=m w
$$

where, $D$ is the digester slurry, $m$ is the manure and $w$ is the distilled water.

In course of carrying out the methodology procedural, the following parameters needed to be accounted for in order to get the mixtures compositions appropriately.

$$
C=\frac{\rho p}{m}
$$

Percentage purity of sulphuric acid $(p)=98 \%$; density of sulphuric acid $(\rho)$ 
$=1.84 \%$; molecular weight or molar mass of sulphuric acid $(m)=98.07 \%$ and the concentration of $\mathrm{H}_{2} \mathrm{SO}_{4}$ is denoted as $C$.

To determine the volume of $\mathrm{H}_{2} \mathrm{SO}_{4}$ in mole required as the acidified water to prevent the dissolution of the gas released hence, implore the relation below:

$$
V_{1} C_{1}=V_{2} C_{2}
$$

where, $V_{1}$ is the unknown volume of $\mathrm{H}_{2} \mathrm{SO}_{4}, C_{1}$ is the concentration of $\mathrm{H}_{2} \mathrm{SO}_{4}$ already estimated; $V_{2}$ is the volume of water required and $C_{2}$ is the concentration of $\mathrm{H}_{2} \mathrm{SO}_{4}$ required.

\subsection{Media Composition Calculations}

The mathematical expression stated below was used to estimate the required media composition to obtain accurate results.

$$
M_{m}=\frac{q_{m}}{t_{m}}
$$

where, $M_{m}$ is the percentage of media material; $q_{m}$ is the quantity of media material of sawdust; $t_{m}$ is the total quantity of media material added to poultry drops.

\subsection{The Waste to Water Ratio (Slurry)}

$$
\begin{array}{ll}
\mathrm{A}=1: 2 \mathrm{w} / \mathrm{v} & \mathrm{E}=1: 2 \mathrm{w} / \mathrm{v} \\
\mathrm{B}=1: 2.2 \mathrm{w} / \mathrm{v} & \mathrm{F}=1: 2.2 \mathrm{w} / \mathrm{v} \\
\mathrm{C}=1: 2.4 \mathrm{w} / \mathrm{v} & \mathrm{G}=1: 2.4 \mathrm{w} / \mathrm{v} \\
\mathrm{D}=1: 2.7 \mathrm{w} / \mathrm{v} & \mathrm{H}=1: 2.7 \mathrm{w} / \mathrm{v} \\
\mathrm{I}=1: 2 \mathrm{w} / \mathrm{v} & \mathrm{M}=1: 2 \mathrm{w} / \mathrm{v} \\
\mathrm{J}=1: 2.2 \mathrm{w} / \mathrm{v} & \mathrm{N}=1: 2.2 \mathrm{w} / \mathrm{v} \\
\mathrm{K}=1: 2.4 \mathrm{w} / \mathrm{v} & \mathrm{O}=1: 2.4 \mathrm{w} / \mathrm{v} \\
\mathrm{L}=1: 2.7 \mathrm{w} / \mathrm{v} & \mathrm{P}=1: 2.7 \mathrm{w} / \mathrm{v}
\end{array}
$$

where, w/v means weight of slurry per volume of water.

\section{Result and Discussion on the Volume of Gas Produced between Mahogany and Iroko Woods}

Table 2 shows by analysis the volume of gas produced from various concentrations of Mahogany and Iroko wood (hard woods).

It was observed that, results from the volume of gas produced from eight digesters of different quantities of media materials were shown in the Table 2. Comparing digester A of Mahogany and digester I of Iroko wood with the same quantity of seedling materials, digester A generated $615 \mathrm{~cm}^{3}$ volume of biogas and had its peak value of $2800 \mathrm{~cm}^{3}$, and a lowest value of $530 \mathrm{~cm}^{3}$ within days $37-40$, while digester I containing Iroko wood generated $400 \mathrm{~cm}^{3}$ and had its maximum value at $2400 \mathrm{~cm}^{3}$ with $330 \mathrm{~cm}^{3}$ least. Likewise, the comparison of rate of biogas produced from digester B of Mahogany wood started from $490 \mathrm{~cm}^{3}$ and attained its maximum value within 13 - 16 days of $2480 \mathrm{~cm}^{3}$ while digester J began with $340 \mathrm{~cm}^{3}$ and rose to a peak value of $2010 \mathrm{~cm}^{3}$ with low biogas produced 
Table 2. Volume of gas produced between Mahogany and Iroko woods.

\begin{tabular}{ccccccccc}
\hline Period (days) & A & B & C & D & I & J & K & L \\
\hline $1-4$ & 615 & 490 & 460 & 400 & 400 & 340 & 320 & 290 \\
$5-8$ & 1750 & 1190 & 995 & 799 & 1200 & 1090 & 900 & 680 \\
$9-12$ & 2215 & 1885 & 1220 & 920 & 2050 & 1400 & 1200 & 890 \\
$13-16$ & 2800 & 2480 & 1820 & 1145 & 2400 & 2010 & 1750 & 1000 \\
$17-20$ & 1480 & 1260 & 1710 & 950 & 1300 & 1100 & 1000 & 790 \\
$21-24$ & 1100 & 950 & 880 & 845 & 940 & 900 & 800 & 510 \\
$25-28$ & 1025 & 920 & 850 & 715 & 600 & 550 & 500 & 400 \\
$29-32$ & 980 & 745 & 850 & 610 & 550 & 450 & 400 & 350 \\
$33-36$ & 690 & 420 & 760 & 300 & 480 & 400 & 350 & 230 \\
$37-40$ & 530 & 395 & 300 & 280 & 330 & 310 & 240 & 200 \\
Total & 13,185 & 10,735 & 9845 & 6964 & 10,250 & 8550 & 7460 & 5340 \\
\hline
\end{tabular}

of $310 \mathrm{~cm}^{3}$. Digester C containing $100 \mathrm{~g}$ of seedling material of Mahogany wood started its biogas produced at $460 \mathrm{~cm}^{3}$, peak value of $1820 \mathrm{~cm}^{3}$ and a low volume of $300 \mathrm{~cm}^{3}$ while digester $\mathrm{K}$ with the same concentration started from $320 \mathrm{~cm}^{3}$ attaining a peak volume of $1750 \mathrm{~cm}^{3}$ and a lowest value of $240 \mathrm{~cm}^{3}$. Similarly, digester D having charged with $50 \mathrm{~g}$ of Mahogany wood commenced biogas production from $400 \mathrm{~cm}^{3}$ with $1145 \mathrm{~cm}^{3}$ peak value at $280 \mathrm{~cm}^{3}$ volume of lowest gas yield while digester $\mathrm{L}$ of the same media composition started from $290 \mathrm{~cm}^{3}$ to $1000 \mathrm{~cm}^{3}$ peak volume at $200 \mathrm{~cm}^{3}$ lowest value. In comparison, the volume of biogas yield in digester A is greater than I. In the same vein, digester B was more than J, digester $\mathrm{C}$ exceeded digester $\mathrm{K}$. Also, the volume of gas produced in digester $\mathrm{D}$ is greater than the amount of gases in digester L. The Mahogany wood exhibited higher gas production performance than Iroko wood characteristics.

\section{Result and Discussion on Biogas Yield between Obeche and Araba Woods}

Table 3 clearly shown the analytical comparison of the volume of gas produced from various concentrations of Obeche and Araba wood (wood).

It was obvious that, the results from the volume of gas production from eight digesters of various quantities of media materials were shown in the table above. Comparing digester $\mathrm{E}$ of Obeche and digester $\mathrm{M}$ of Araba wood with the same quantity of seeding materials $(200 \mathrm{~g})$, digester E commenced its produce from $260 \mathrm{~cm}^{3}$ and had its peak volume of $1130 \mathrm{~cm}^{3}$ and a lowest value of $170 \mathrm{~cm}^{3}$ within day 37 - 40 while digester M containing Araba wood started its biogas production from $280 \mathrm{~cm}^{3}$ and has its maximum volume at $1200 \mathrm{~cm}^{3}$ with $200 \mathrm{~cm}^{3}$ low. Similarly, the comparison of rate of biogas produced from digester $\mathrm{F}$ of Obeche wood started from $200 \mathrm{~cm}^{3}$ and attained its peak volume within days 13 - 16 of $875 \mathrm{~cm}^{3}$ and rose to a peak volume of $10,409 \mathrm{~cm}^{3}$ with lowest biogas produced of $170 \mathrm{~cm}^{3}$. Digester D containing $100 \mathrm{~g}$ of seeding materials of Obeche wood started its production at $240 \mathrm{~cm}^{3}$ with a peak volume of $740 \mathrm{~cm}^{3}$ and a 
Table 3. Volume of biogas yields between Obeche and Araba woods.

\begin{tabular}{ccccccccc}
\hline Period (days) & $\mathrm{E}$ & $\mathrm{F}$ & $\mathrm{G}$ & $\mathrm{H}$ & $\mathrm{M}$ & $\mathrm{N}$ & $\mathrm{O}$ & $\mathrm{P}$ \\
\hline $1-4$ & 260 & 200 & 240 & 85 & 280 & 200 & 150 & 100 \\
$5-8$ & 600 & 320 & 360 & 125 & 800 & 700 & 440 & 300 \\
$9-12$ & 1000 & 530 & 700 & 290 & 1140 & 970 & 800 & 780 \\
$13-16$ & 1130 & 875 & 740 & 710 & 1200 & 1040 & 900 & 790 \\
$17-20$ & 800 & 510 & 345 & 520 & 930 & 840 & 650 & 450 \\
$21-24$ & 790 & 425 & 280 & 295 & 790 & 610 & 450 & 290 \\
$25-28$ & 760 & 415 & 215 & 200 & 690 & 400 & 320 & 230 \\
$29-32$ & 675 & 350 & 170 & 100 & 640 & 380 & 300 & 230 \\
$33-36$ & 260 & 320 & 140 & 80 & 320 & 295 & 250 & 180 \\
$37-40$ & 170 & 120 & 100 & 60 & 200 & 170 & 120 & 80 \\
Total & 6445 & 4065 & 3290 & 2465 & 6990 & 5605 & 4380 & 3430 \\
\hline
\end{tabular}

Table 4. Volume of biogas produced from various concentrations of Mahogany, Iroko, Araba and Obeche media.

\begin{tabular}{ccccc}
\hline Digester & A - D & E - H & I - L & M - P \\
\hline Period Days & Mahogany $\left(\mathrm{cm}^{3}\right)$ & Iroko $\left(\mathrm{cm}^{3}\right)$ & Araba $\left(\mathrm{cm}^{3}\right)$ & Obeche $\left(\mathrm{cm}^{3}\right)$ \\
\hline $0-4$ & 1965 & 1350 & 730 & 785 \\
$5-8$ & 4734 & 3870 & 2240 & 1405 \\
$9-12$ & 6240 & 5540 & 3690 & 2520 \\
$13-16$ & 8245 & 7160 & 3930 & 3455 \\
$17-20$ & 5400 & 4190 & 2870 & 2175 \\
$21-24$ & 3775 & 3150 & 2140 & 1790 \\
$25-28$ & 2510 & 2050 & 1640 & 1590 \\
$29-32$ & 3185 & 1750 & 1550 & 1295 \\
$33-36$ & 2170 & 1460 & 1045 & 800 \\
$37-40$ & 1505 & 1080 & 570 & 450 \\
Total & 39,729 & 31,600 & 20,405 & 16,265 \\
\hline
\end{tabular}

lowest value of $100 \mathrm{~cm}^{3}$ while digester $\mathrm{O}$ with the same quantity content started from $150 \mathrm{~cm}^{3}$ attaining a peak volume of $900 \mathrm{~cm}^{3}$ with a lowest volume of 250 $\mathrm{cm}^{3}$. Digester $\mathrm{H}$ having $50 \mathrm{~g}$ of Obeche wood commenced biogas production from $85 \mathrm{~cm}^{3}$ with $710 \mathrm{~cm}^{3}$ peak value at $60 \mathrm{~cm}^{3}$ lowest gas yield while, digester $P$ of the same composition started from $100 \mathrm{~cm}^{3}$ to a peak value of $790 \mathrm{~cm}^{3}$ of Araba wood at $80 \mathrm{~cm}^{3}$ lowest value. On comparison, volume of biogas produced in digester $\mathrm{M}$ was greater than $\mathrm{E}$, digester $\mathrm{N}$ had more gas yield than $\mathrm{F}$ as well as digester $\mathrm{O}$ recorded exceeded biogas yield than $\mathrm{G}$. In addition, the volume of gas produced in digester $\mathrm{P}$ was greater than the amount of gases in digester $\mathrm{H}$. The analysis above showed that, Araba wood specie exhibited higher biogas production than Obeche wood characteristics.

Table 4 illustrates the summary of the total volume of biogas produced from 
various concentrations of Mahogany, Iroko, Araba and Obeche media.

Table 4 clearly shows that the four different species of wood tested indicated low gas produce in 0 - 4 days. It was noted that, the retention rate time of the anaerobic process was 13 - 16 days via Mahogany $\left(8245 \mathrm{~cm}^{3}\right)$, Iroko $\left(7160 \mathrm{~cm}^{3}\right)$, Araba with $3930 \mathrm{~cm}^{3}$, and Obeche yielding $3455 \mathrm{~cm}^{3}$ as the peak period of yielding the highest volume of biogas. After the retention rate time, the volume of gas production drops with respect to successive days. In the long run, Mahogany (hard wood) as a media material generated the highest gas via $39,729 \mathrm{~cm}^{3}$ followed by $31,600 \mathrm{~cm}^{3}$ of Iroko (hard wood). It was depicted by Table 4 that, $20,405 \mathrm{~cm}^{3}$ of Araba (soft wood) was generated while Obeche (soft wood) produced 16,265 $\mathrm{cm}^{3}$ volume of biogas. The behavioural patterns of different species of the tested woods were represented in a multiple bar chart as indicated in Figure 1 below.

It was obvious from Figure 1 that, among the four researched woods as seedling media materials in the biogas production, Mahogany $\left(39,729 \mathrm{~cm}^{3}\right)$ yielded the highest volume of biogas followed by Iroko wood $\left(31,600 \mathrm{~cm}^{3}\right)$ that were both hard woods while, Araba $\left(20,405 \mathrm{~cm}^{3}\right)$ over weighs Obeche wood $\left(16,265 \mathrm{~cm}^{3}\right)$ in the volume of gas produced.

\section{Conclusion}

The tremendous increases in the costs of convectional fuels in the urban areas necessitate the exploration of other energy sources. Biogas could be produced from animal wastes, wood wastes and other bio-wastes as a substitute for fossils fuels. The search for alternative energy sources such as biogas should be intensified so that, ecological disasters like deforestation could be solved. This paper

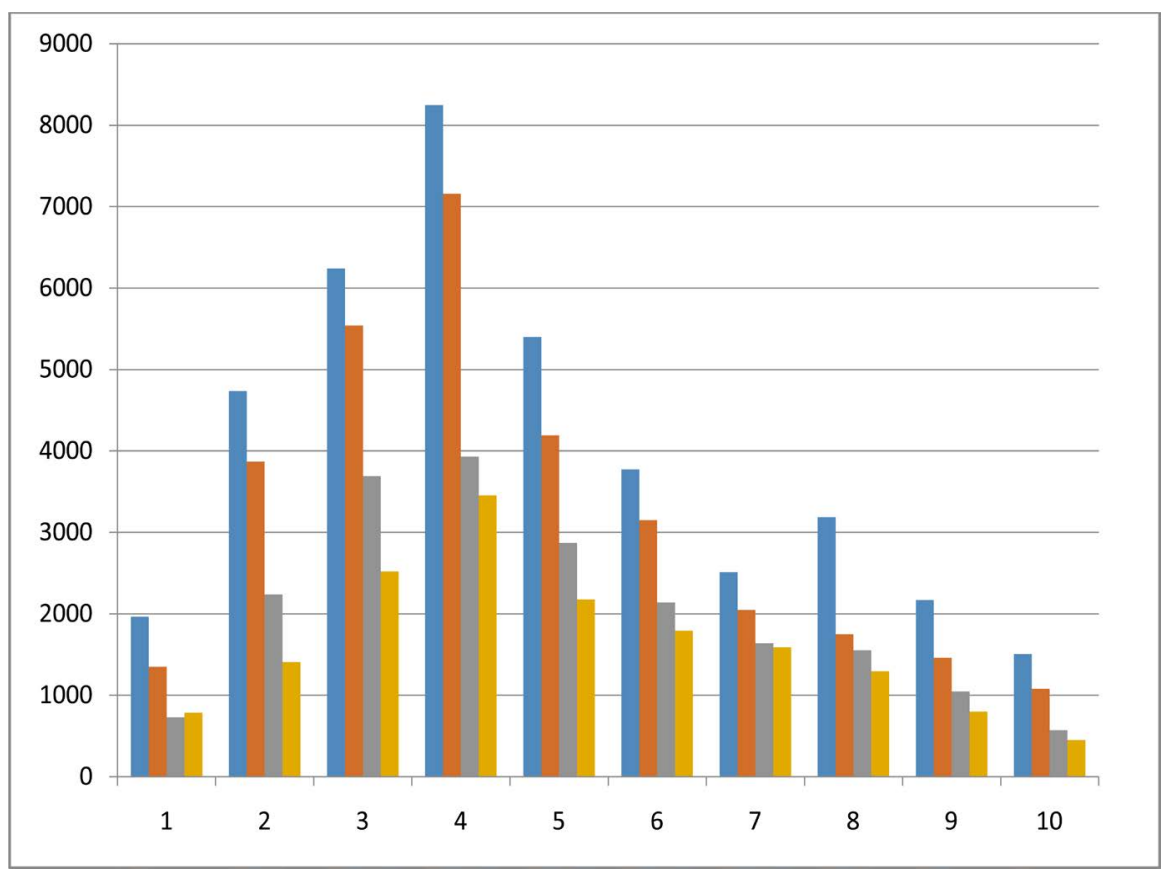

Figure 1. Multiple bar charts of the volume of biogas produced from various concentrations of Mahogany, Iroko, Araba and Obeche media. 
has shown an increase in the production of biogas through the use of varying quantities of seedling materials (wood species). The various concentrations of the two hard woods (Mahogany and Iroko) are regarded as the most reliable and strong woods in Africa setting, exhibiting good and better characteristics in accelerating biogas yield than the two soft woods (Araba and Obeche) that top its species. However, Mahogany wood had distinguished its media potentials unique content in generating the highest rate of biogas production among other tested wood species. The rate of biogas production was directly proportional to the quantity of the seedling materials to obtain a reliable result. In search for other means of improving biogas yields and enhancing the efficiency of the domestic usage, further studies should be intensified for the easier liquidification and compressibility of this gas for better domestic storage and practical usage in driving engines, powering domestic electrical appliances and power stations at large.

\section{References}

[1] Adeyemo, S.B. (2001) Energy Potentials of Organic Wastes. In: Proceedings of the 1 st National Conference on Manufacturing Technology and Engineering in a Development Economy, University of Uyo, 56-61.

[2] Jagadeesh, K.S. (1986). Proceedings of the International Conference on Biogas Energy Systems. New Delhi, 22-23.

[3] Sharma, S.K., Mishra, I.M., Sharma, M.P. and Saini, J.S. (1988) Biomass, an Alternative Energy. Indian Journal of Environmental Health, 17, 251-263.

[4] Bolte, J.P., Hill, D.T. and Wood, T.H. (1986) Anaerobic Digestion of Screened Waste Liquids in Suspends Particles. Attached Growth Reactors. Transactions of the ASAE, 29, 543-549. https://doi.org/10.13031/2013.30188

[5] Chawla, O.P. (1986) Advances in Biogas Technology. India Council of Agricultural Research, New Delhi, 144.

[6] Meher, K.K., Ranade, D.R. and Gadre, R.V. (1990) Design of Biogas Plant. Research Ind., 115-117.

[7] Lagrange, B. (1979) Biomethana2: Principles Techniques and Utilization. EDISUD.

[8] Gadre, R.V., Ranade, D.R. and God-bole, S.H. (1990) Biogas Production from Cattle Dung. Indian Journal of Environmental Health, 32, 45-49.

[9] Yadaua, L.S. and Hesse, P.R. (1981) The Development and Use of Biogas in Rural Areas of Asia; Improving Soil Fertility through Organic Recycling. FAO/UNDP Regional Project RAS/75/004 Project Field Document No. 10.

[10] Fry, J.L. (2004) Methane Digesters for Fuel, Gas and Fertilizer. Santa Barbara.

[11] Luad, M.S., Anderson, S.S. and Torry-Smith, M. (1996) Building of a Flexibility Bag Biogas Digester in Tanzania. Student Report Technical University of Denmark, Copenhagen.

[12] Ranade, D.R., Nagarwala, N., Dudhbhate, J.A., Gadre, R.V. and God-bole, S.H. (1990) Influence of Different Total Solids Content on Biogas Production. Indian Journal of Environmental Health, 32, 63-65.

[13] Da-Silva, E.J. (1979) Biogas Generation Developments; Problems and Tasks Overview Division of Scientific Research and Higher Education. UNESCO, Paris, 1-19. 
Submit or recommend next manuscript to SCIRP and we will provide best service for you:

Accepting pre-submission inquiries through Email, Facebook, LinkedIn, Twitter, etc. A wide selection of journals (inclusive of 9 subjects, more than 200 journals)

Providing 24-hour high-quality service

User-friendly online submission system

Fair and swift peer-review system

Efficient typesetting and proofreading procedure

Display of the result of downloads and visits, as well as the number of cited articles Maximum dissemination of your research work

Submit your manuscript at: http://papersubmission.scirp.org/

Or contact wjet@scirp.org 